\title{
Osteosarcoma contains a subpopulation of cancer stem-like cells that are highly resistant to radiotherapy
}

\author{
Sara RM Neves ${ }^{1 *}$, Aurio OG Lopes ${ }^{1}$, Anália do Carmo ${ }^{2}$, Antero J Abrunhosa ${ }^{3}$, Paulo CPS Simões ${ }^{4}$, Artur A Paiva ${ }^{5}$, \\ M Filomena Botelho', Célia MF Gomes ${ }^{1}$
}

From 16th International Charles Heidelberger Symposium on Cancer Research

Coimbra, Portugal. 26-28 September 2010

\section{Aim}

The cancer stem cell (CSC) theory states that tumors contain a subset of cells responsible for tumor initiation and growth and recurrence after treatments. We aimed to identify the presence of putative CSCs in a human MNNG/HOS osteosarcoma cell line and investigate their role in response to radiotherapy.

\section{Methods}

The isolation of CSCs was performed using the sphere formation assay in serum-free medium in non-adherent conditions. The cells were characterized for the expression of mesenchymal stem cell markers $\left(\mathrm{CD}^{+} 0^{+} /\right.$ $\mathrm{CD} 105^{+} / \mathrm{CD} 73^{+}$) by flow cytometry. MNNG/HOS and CSCs were irradiated with X-rays at different doses (020Gy). The sensitivity to ionizing radiation was evaluated using the MTT assay after 7 days. Cell-cycle responses were studied at $24 \mathrm{~h}$ post-irradiation using propidium iodide staining.

\section{Results}

A subset of CSCs was identified in the MNNG/HOS cell line. The isolated cells formed sphere-clusters and were positive for MSC markers. The mean lethal dose (LD50) obtained for CSCs was of $8.0 \pm 3.0 \mathrm{~Gy}$, significantly higher than for MNNG/HOS cells $(\mathrm{LD} 50=3.4 \pm 0.6 \mathrm{~Gy}$, $\mathrm{p}<0.05)$. It was observed a dose dependent cell-cycle arrest in $\mathrm{G}_{2} / \mathrm{M}$ phase at $24 \mathrm{~h}$, in the MNNG/HOS cells. CSCs cell-cycle progression remained unaltered.

\footnotetext{
* Correspondence: sara.neves87@gmail.com

'Institute of Biophysics and Biomathematics - IBILI - FMUC, Coimbra, Portugal
} Full list of author information is available at the end of the article

\section{Conclusions}

Osteosarcoma contains a subset of cells with stem-like properties that are relatively resistant to radiation. The absence of alterations in cell-cycle progression of CSCs suggests that these cells may have higher capacity to repair the irradiation-induced DNA lesions and increased DNA damage checkpoints signaling. These results suggest that radiotherapy may not address the CSCs subpopulation allowing them to survive and regenerate the tumor.

\section{Author details \\ 'Institute of Biophysics and Biomathematics - IBILI - FMUC, Coimbra, Portugal. ${ }^{2}$ Center for Neurosciences and Cell Biology - CNC, Coimbra, Portugal. Institute for Nuclear Sciences Applied to Health - ICNAS, Coimbra, Portugal. ${ }^{4}$ Radiotherapy Service - University Hospital of Coimbra, Coimbra, Portugal. ${ }^{5}$ Histocompatibility Centre of Coimbra - University Hospital of Coimbra, Coimbra, Portugal.}

Published: 24 September 2010

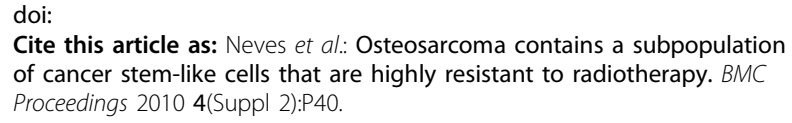

Cite this article as: Neves et al:: Osteosarcoma contains a subpopulation of cancer stem-like cells that are highly resistant to radiotherapy. BMC Proceedings 2010 4(Suppl 2):P40.

Submit your next manuscript to BioMed Central and take full advantage of:

- Convenient online submission

- Thorough peer review

- No space constraints or color figure charges

- Immediate publication on acceptance

- Inclusion in PubMed, CAS, Scopus and Google Scholar

- Research which is freely available for redistribution

Submit your manuscript at www.biomedcentral.com/submit
C Biomed Central 